\title{
Pengaruh Kepemimpinan Instruksional Terhadap Peningkatan Keaktifan Belajar dan Hasil Belajar Peserta Didik
}

\author{
Yuliana Pebristofora Marni Mala ${ }^{1}$, Erny Roesminingsih², Yatim Riyanto ${ }^{3}$,Bambang Sigit \\ Widodo ${ }^{4}$ \\ ${ }^{1234}$ Surabaya State University \\ yuliana.19015@mhs.unesa.ac.id
}

\begin{abstract}
Instructional leadership is strategically used to improve the quality of learning. This leadership style is leadership oriented to improve the quality of learning, instructional leadership policy becomes the parameters of the school in improving the quality of learners' learning outcomes. The purpose of the study was: knowing and analyzing the influence of instructional leadership models, improving learning activity on student learning outcomes. This research uses quantitative research method. Data collection using research instruments by disseminating questionnaires using google form. The results of this study are: (1) there is an influence of instructional leadership model on improving the activeness of learners' learning; (2) there is an influence of instructional leadership model on learners' learning outcomes; and (3) there is an influence of instructional leadership on improving the activeness of learning and learning outcomes of learners. It can be concluded that instructional leadership is effective in improving the quality of learning.
\end{abstract}

Keywords: Instructional Leadership, Principal, Learning Activity, Learning Outcomes.

Abstrak. Kepemimpinan instruksional sangat strategis digunakan untuk meningkatkan mutu pembelajaran. Gaya kepemimpinan ini berorientasi pada kepemimpinan untuk meningkatkan kualitas pembelajaran, kebijakan kepemimpinan instruksional menjadi parameter sekolah dalam meningkatkan kualitas hasil belajar peserta didik. Tujuan penelitian adalah: mengetahui dan menganalisis pengaruh model kepemimpinan instruksional, peningkatan Keaktifan belajar terhadap hasil belajar peserta didik. Penelitian ini menggunakan metode penelitian kuantitatif. Pengumpulan data menggunakan instrumen penelitian dengan menyebarkan kuisioner menggunakan google form. Hasil penelitian ini adalah: (1) ada pengaruh model kepemimpinan instruksional terhadap peningkatan keaktifan belajar peserta didik; (2) ada pengaruh model kepemimpinan instruksional terhadap hasil belajar peserta didik; dan (3) ada pengaruh kepemimpinan instruksional terhadap peningkatan keaktifan belajar dan hasil belajar peserta didik. Dapat disimpulkan bahwa kepemimpinan instruksional efektif meningkatkan kualitas pembelajaran.

Kata Kunci: Kepemimpinan Instruksional, Kepala Sekolah, Keaktifan Belajar, Hasil Belajar.

\section{PENDAHULUAN}

Lembaga Pendidikan sebagai organisasi Sekolah dalam pendidikan yang di dalamnya terdapat kepala sekolah, guru-guru, staf karyawan, peserta didik, dan orang tua peserta didik yang melakukan hubungan keja sama untuk mencapai suatu tujuan. Kepala sekolah adalah seseorang yang diberi tugas untuk memimpin sekolah, bertanggungjawab atas tercapainya tujuan sekolah. Kepala sekolah menjadi pemimpin dan inovator di sekolah. Maka kualitas kepemimpinanya adalah hal yang sangat penting bagi keberhasilan sekolah. Kemampuan profesional kepala sekolah sebagai pemimpin pendidikan yaitu bertanggung jawab dalam menciptakan suatu situasi belajar mengajar yang kondusif, sehingga guru-guru dapat melaksanakan pembelajaran dengan baik dan peserta didik dapat belajar dengan tenang serta visi dan misi sekolah dan tujuan dari pendidikan dapat tercapai sesuai dengan yang diinginkan. Seseorang dipilih menjadi seorang pemimpin karena dipercaya bukan hanya kejujuranya saha tetapi niat yang dibangun dari dalam dirinya bahwa kunci keberhasilan ada dalam dirinya sebagai panutan bawahanya agar menjadi taat, 
hormat, setia dan mudah bekerja sama (Gill, 2009) tentu saja output dari segala rangkaian stake holder dalam Lembaga Pendidikan adalah peserta didik, bagaimana segala rangkaian dijalankan agar menghasilkan peserta didik yang unggul dan berkualitas. Banyak model kepemimpinan yang diterapkan seorang kepala sekolah dalam Lembaga Pendidikan yang dipimpinya, tetapi sampai sekarang belum ada satupun yang menunjukan pengaruh kepemimpinan yang hasilnya signifikan dalam mengembangkan Lembaga Pendidikan.

Seorang kepala sekolah adalah panutan guruguru dan peserta didik serta menjadi pencetus budaya yang diamalkan di sekolah, tindakantindakan yang diambilnya mencerminkan gaya kepemimpinanya. Berdasarkan analisis yang dinyatakan (Hughes \& Noris; 2001) Kepemimpinan instruksioanl yang ditonjolkan oleh seorang kepala sekolah menunjukan tahap keterlibatan tinggi dalam kerja dan berorientasikan akademik. Kesan Tindakan kepala sekolah yang mengamalkan kepemimpinan instruksional boleh diukur melalui penglibatanya dalam dua proses memimpin yaitu pencapaian tujuan, visi misi dan kesejahteraan masyarakat sekolah. Ciri lain yang dimiliki kepemimpinan instruksional selain memberikan motivasi guru-guru secara mental juga menyediakan perangkat yang dapat membantu guru dalam melaksanakan tugastugasnya seperti perlengkapan laboratorium ataupun media yang dapat membantu guru dalam melancarkan kegiatan belajar mengajar. Dengan begini guru akan merasa termotivasi dan merasa didukung sehingga akan melahirkan rasa hormat dan percaya terhadap pemimpin. seperti yang dikutip dalam (Covey, Whitman \& England; 2010) Kepercayaan adalah bentuk tertinggi motivasi manusia dan kemampuan pemimpin untuk meraih kepercayaan dari bawahanya menjadi stimulus dalam meningkatkan motivasi kerja. Melalui peranan sebagai seorang pimpinan, kepemimpinan instruksional mengamati dan menginstruksikan dalam meningkatkan lingkungan belajar di sekolah. Pemantauan atau supervisi yang dilakukan bertujuan untuk mengevaluasi keefektifan belajar mengajar, memberikan bimbingan, dan dorongan. Hal ini mampu meningkatkan kualitas penyampaian pengajaran guru secara terus menerus dan memastikan pencapaian tujuan pembelajaran sejalan dengan tujuan sekolah, potensi yang dimiliki pemimpin instruksional dapat mencapai prestasi peserta didik dengan meningkatkan keaktifan belajar dan hasil belajar.

Pendekatan kepemimpinan yang strategis untuk digunakan adalah kepemimpinan instruksional. Kepemimpinan instruksional memperdayakan segenap kemampuan stakeholder yang bermutu yang akan membantu meningkatkan proses dan hasil belajar peserta didik secara tidak langsung. (Whitehead, 2012) menggambarkan kepemimpinan instruksional dalam 4 poin penting dimana kepemimpin instruksional kepala sekolah berfungsi untuk melayani dan membimbing guru dalam meningkatkan pengalaman belajar yang produktif. Selain itu bertanggung jawab untuk menyelesaikan masalah dan sumber daya dalam memodifikasi proses belajar mengajar. Sebagai seorang pemimpin yang visioner, Kepala sekolah diharapkan dapat mengembangkan citra sekolah yang ideal dan menjadi agen perubahan dalam memperbaharui operasional efektivitas Lembaga pendidkan.

(Bush, 2008:4) menyatakan bahwa pemimpin adalah orang yang menentukan tujuan-tujuan, memotivasi, dan menindak bawahanya. Pemimpin adalah orang yang memimpin, mengorganisasikan segala kegiatan yang berjalan di sekolah. (Smith \& Piele, 2012) mengatakan kepemimpinan sekolah adalah "The activity of mobilizing and empowering others to serve the academic and related needs of students with utmost skill and integrity." Kepemimpinan dalam sebuah Lembaga Pendidikan menjadi center Lembaga itu bergerak dengan memberikan pelayanan akademik sesuai kebutuhan siswa, termasuk ketrampilan dan intergritas peserta didik.

Kepala sekolah memiliki peran center dalam menjalankan kepemimpinan, profesionalnya seorang kepala sekolah menjadi salah satu kualitas dalam memimpin, bagaimana seorang kepala sekolah mampu membangkitkan motivasi tenaga pendidik hingga bagaimana kepala sekolah bertanggung jawab pada kreatifitas guru dan menjadikanya prestasi tenaga pendidik, Motivasi berprestasi tenaga pendidik terkait 
hubungan dengan hasil peserta didik nantinya, dalam hal ini adalah guru yang menjadi stimulus serta memiliki kesempatan untuk mengamati lebih dekat peserta didik tentu akan mempengaruhi prestasi peserta didiknya.

Formulasi kepemimpinan instruksional diasumsikan sebagai tanggung jawab kepala sekolah. Oleh karena itu, ukuran kepemimpinan seperti Skala Peringkat Manajemen Instruksional Kepala Sekolah (PIMRS) (Hallinger \&Murphy, 1986), hanya berfokus pada kepala sekolah dan mengabaikan kontribusi staf lain untuk penetapan tujuan instruksional, pengawasan program pengajaran, dan pengembangan budaya akademik dan pembelajaran yang positif. Fokus eksklusif pada kepala sekolah memperkuat pandangan heroik tentang peran yang hanya sedikit tercapai (Hallinger, 2005). Penelitian terbaru memiliki fokus yang lebih inklusif dengan banyak ukuran mencakup kepala sekolah yang berada dalam posisi tanggung jawab dan kepemimpinan instruksional (Marks \&Printy, 2003). Tinjauan terbaru tentang dampak kepemimpinan instruksional adalah "Ukuran efek itu secara tidak langsung kepala sekolah berkontribusi terhadap pembelajaran peserta didik".

Kepemimpinan instruksional secara keseluruhanya adalah suatu gaya kepemimpinan yang komperhensif dan memiliki potensi tinggi dalam memotivasi guru dengan penekanan dalam memantau peserta didik. Pemantauan yang dijalankan bertujuan menilai proses kegiatan belajar mengajar, memberi bimbingan serta dorongan agar mampu meningkatkan keaktifan belajar dan hasil belajar hingga melahirkan murid yang cemerlang karena peranan utama seorang pemimpin di sekolah, sehingga pencapaian peserta didik dan sekolah umumnya dapat ditingkatkan melalaui kepemimpinan ini.

(Hallinger \& Murphy, 1986) Dimensi kedua Mengelola Program Instruksional berfokus pada koordinasi dan pengendalian instruksi dan kurikulum. Dimensi ini menggabungkan tiga fungsi kepemimpinan yaitu; Mengawasi mengkoordinasi dan Mengevaluasi serta Memantau kemajuan peserta didik. Kepemimpinan instruksional menuntut kepala sekolah memiliki keahlian dalam belajar mengajar, serta komitmen terhadap peningkatan sekolah salah satunya adala peningkatan hasil belajar peserta didik. Hal ini mencerminkan tingkat keterlibatan kepala sekolah ini dalam memantau kemajuan peserta didik dalam mengelola program instruksional sekolah.

Bagi penyelesaian masalah di atas (Hallinger \& Murphy, 1985) meletakan 11 elemen mendasarkan 3 dimensi utama yang menjelaskan bahwa kepemimpinan instruksional secara tidak langsung meningkatkan keaktifan dan hasil belajar peserta didik dapat digambarkan seperti gambar di bawah ini.

Gambar 1: 3 Dimensi Mendasari 11 Elemen Kepemimpinan Instruksional Hallinger \& Murphy (1985)

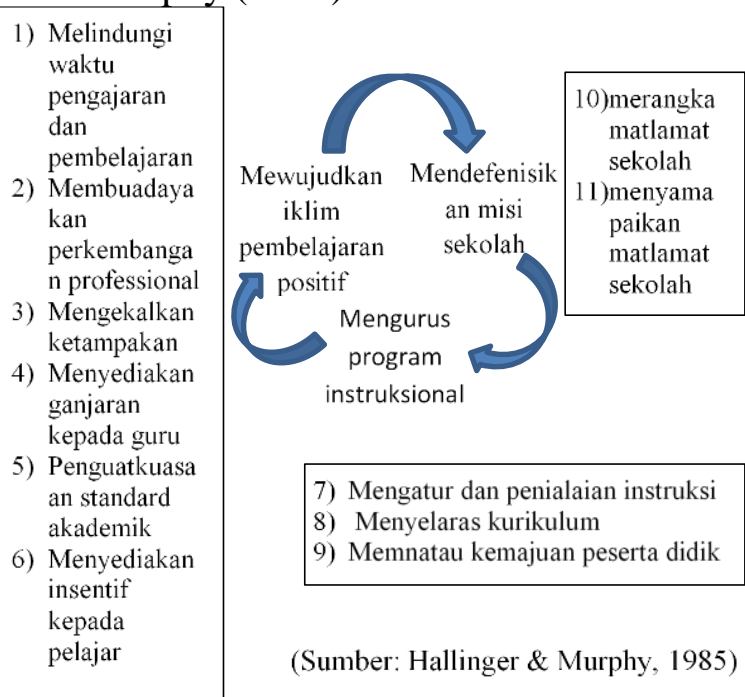

Gambar di atas menunjukkan bahwa kepemimpinan instruksional kepala sekolah menempatkan tiga hal pokok yang menjadi titik fokus yaitu mewujudkan iklim pembelajaran yang positif yang merangkum 6 elemen, kemudian bagaimana misi sekolah itu dapat diimpelentasikan dan yang terakhir mengurus program instruksional.

Penyelesaian masalah di atas menekankan pada kepemimpinan instruksional kepala sekolah yang membudayakan perkembangan professional guru yang menjelaskan berkualitasnya seorang guru dan menyediakan ganjaran pada guru yang dapat merangsang setiap individu untuk lebih produktif dan komitmen terhadap tugas. Semua konsep yang di atur oleh kepemimpinan instruksional seorang kepala sekolah bermuara pada peserta didik. Sebagai stimulus seorang guru yang professional, kreatif dan berkualitas. 
Guru adalah pendidik professional dengan tugas utama mendidik, mengajar, membimbing, mengarahkan, melatih, menilai, dan mengevaluasi peserta didik pada Pendidikan. Guru kreatif adalah guru yang mampu membuat peserta didik berpikir besar dan melakukan berbagai hal yang inovatif, berusaha mempelajari metode-metode baru untuk mendapatkan pengetahuan baru dan mengimplementasikan seefektif mungkin. Seorang guru yang selalu siap dalam situasi apapun dan mempersiapkan diri dalam keadaan apapun serta memiliki kebebasan untuk mengeksplorasi alternatif terhadap persoalan yang dihadapi setiap hari tiada henti sehingga memberikan inspirasi, motivasi terhadap peserta didik. Seorang Guru yang berkualitas adalah guru dapat memanfaatkan kemajuan teknologi untuk mengembangkan cara belajar yang baik dan tidak terbawa arus dampak negative dengan kemajuan teknologi yang ada.

Dapat disimpulkan bahwa kepemimpinan instruksional adalah kepemimpinan yang fokus pada proses dan hasil belajar peserta didik melalui pemberdayaan guru yang professional, kreatif dan berkualitas.

Oleh karena itu peneliti melakukan penelitian dengan judul pengaruh kepemimpinan instruksional terhadap peningkatan keaktifan belajar dan hasil belajar peserta didik sehingga prestasi siswa dan sekolah umumnya dapat ditingkatkan melalui kepemimpinan ini.

\section{METODE}

Pendekatan penelitian yang digunakan dalam penelitian ini adalah analisis deskriptif dengan pendekatan kuantitatif. Populasi dalam penelitian ini adalah guru tingkat SMP dan SMA Kabupaten Manggarai Nusa Tenggara Timur. Dengan jumlah sampel 32 responden. Teknik analisis data yang dilakukan adalah korelasi parsial, korelasi ganda dan regresi ganda dalam menganalisis hubungan dua variabel yang dinyatakan dengan persamaan $Y^{\prime}=a+b X$. Teknik pengumpulan data menggunakan kuisioner yang dibuat dalam bentuk Google form, sehingga sangat mudah untuk dibagikan pada guru-guru melalui media social dimasa pandemic ini. Data yang dikumpulkan berupa data interval, kuisioner diberi skor ekuivalen (setara) dengan 4 skala interval berbeda.
Tabel 1.1: Tabel Silang Komposisi Responden Berdasarkan Posisi Jabatan

\begin{tabular}{|c|c|c|}
\hline No & Posisi Jabatan & $\begin{array}{c}\text { Jumlah } \\
\text { Responden }\end{array}$ \\
\hline 1. & Kepala Sekolah & 2 \\
\hline 2. & Guru & 30 \\
\hline \multicolumn{2}{|c|}{ Total } & $\mathbf{3 2}$ \\
\hline
\end{tabular}

\section{HASIL DAN PEMBAHASAN}

Berdasarkan hasil penelitian yang diperoleh bahwa skor kepemimpinan instruksional menyebar dari skor terendah dengan skor 1 sampai skor teoritis dan empiric tertinggi dengan skor 16 dan rentangan data 15. Dari hasil pengolahan data diperoleh skor rata-rata 8 , Median 7,5 dan standar deviasi sebesar 5,078.

Berdasarkan hasil penelitian menunjukan pengaruh kepemimpinan instruksional terhadap peningkatan keaktifan dan hasil belajar peserta didik menunjukan masing-masing presentasi berdasarkan 4 kategori kuisioner yaitu; kategori Kurang baik dengan persentasi 3,75\%, kategori cukup baik 20,15\%, kategori baik dengan presentasi 48,28\% dan kategori sangat baik dengan presentasi $27,81 \%$. Dari hasil presentasi yang didapatkan dari penelitian menyatakan bahwa kepemimpinan instruksional memiliki pengaruh terhadap peningkatan keaktifan dan hasil belajar peserta didik dengan presentasi tertinggi pada kategori baik. Berdasarkan hasil analisis untuk uji deskriptif, dapat dilakukan interpretasi menggunakan analisis deskriptif.

Tanggapan responden terhadap pernyataan kepemimpinan instruksional memiliki skor minimum 1 dan skor maximum 16 dengan mean 8.00 dan standar deviasi 5,078 yang berarti bahwa tanggapan responden terhadap pernyataan kepemimpinan instruksional dinilai baik.

Analisis korelasi antara variable kepemimpinan instruksional kepala sekolah terhadap peningkatan keaktifan dan hasil belajar peserta didik adalah berdasarkan nilai signifikansi diketahui nilai Sig. antara Kepemimpinan Instruksional (Y) dengan Keaktifan belajar (X1) dan Hasil belajar peserta didik (X2) terlihat bahwa korelasi antara masingmasing indikator menunjukan hasil yang signifikan. Kepemimpinan instruksional (Y) dengan keaktifan belajar (X1) memiliki nilai Sig 0,007. kepemimpinan instruksional (Y) 
dengan Hasil belajar (X2) memiliki nilai Sig 0,003 dan keaktifan belajar (X1) dengan hasil belajar (X2) memiliki nilai Sig 0,000 yang berarti terdapat korelasi yang signifikan antara masing-masing variabel dimana nilai Sig $<0,05$. Dapat disimpulkan bahwa masing-masing indikator pernyataan adalah valid.

Berdasarkan nilai $r$ hitung (pearson correlation) diketahui nilai $r$ hitung untuk hubungan kepemimpinan instruksional $(\mathrm{Y})=$ 0,596 , peningkatan keaktifan $(\mathrm{X} 1)=0,762$ dan hasil belajar $(X 2)=0,797$. Nilai corrected item total korelasi semuanya bernilai positif dan lebih besar dari $r$ table ( $r$ hitung > 0,296). Berdasarkan analisis korelasi ganda diperoleh perhitungan koefisien korelasi ganda $\left(\mathrm{r}_{\mathrm{y} 12}\right)$ sebesar 0,601 , dan nilai probabilitas (sig.F change) $=0,022$. Karena nilai sig.F change $0,022<0,05$, Maka berdasarkan pengambilan keputusan dalam analisis korelasi di atas dapat disimpulkan bahwa ada korelasi atau hubungan antara kepemimpinan instruksional dengan peningkatan keaktifan dan hasil belajar peserta didik. Demikian dapat diartikan bahwa item pada kuisioner tersebut adalah valid.

Persamaan regresi linear ganda pengaruh kepemimpinan terhadap peningkatan kekatifan belajar dan hasil belajar peserta didik $\mathrm{Y}=4,412$ $+0,163 X_{1}+0,341 X_{2}$. Uji keberartian koefisien regresi secara keseluruhan menghasilkan $F$ hitung 4,796 > 0,051 F tabel, secara simultan kepemimpinan instruksional berpengaruh terhadap peningkatan keaktifan dan hasil belajar peserta didik.

Berdasarkan data kuisioner yang dibagikan, semua kriteria kinerja mendapat respon baik dimana (1) Kepala sekolah mengimplementasikan model kepemimpinan instruksional; (2) Kepala skolah sebagai pemimpin berupaya dalam menangani masalah peningkatan proses belajar dan hasil belajar peserta didik; (3) Model kepemimpinan instruksional menjadi salah satu model kepemimpinan yang diimplementasikan untuk meningkatkan proses belajar dan hasil belajar peserta didik; (4) Model kepemimpinan instruksional berpengaruh dalam meningkatkan proses belajar dan hasil belajar peserta didik; (5) Kepala sekolah menginstruksi sistematika pembelajaran sesuai dengan kurikulum yang berlaku; (6) Pemimpin memberikan instruksi layanan orientasi berupaya menyampaikan atau mengingatkan mengenai peraturan yang ada di sekolah dalam meningkatkan proses belajar dan hasil belajar peserta didik; (7) Pemimpin mengintruksi kegiatan-kegiatan di kelas untuk meningkatkan proses belajar dan hasil belajar peserta didik; (8) Pemimpin mengintruksi guru dalam pembuatan Rencana Pelaksanaan Pembelajaran (RPP) dalam meningkatkan prose belajar dan hasil belajar peserta didik; (9) Pemimpin mengelola dan memanfaatkan lingkungan sebagai sumber dan media pembelajaran agar dapat meningkatkan proses belajar dan hasil belajar peserta didik; (10) Pemimpin memberi instruksi kepada guru dalam mengembangkan berpikir kritis peserta didik untuk meningkatkan proses belajar dan hasil belajar (11) Pemimpin menginstruksi interaksi antar masyarakat sekolah agar terciptanya susasana yang nyaman agar dapat meningkatkan proses belajar dan hasil belajar; (12) Sebagai pemimpin instruksional, kepala sekolah professional dalam menginstruksi guru dalam menggunakan media pembelajaran untuk meningkatkan proses belajar dan hasil belajar peserta didik; (13) Pemimpin menginstruksi bekerja sama dengan anggota kelompok untuk menyusun tugasnya dalam menignkatkan proses belajar dan hasil belajar; (14) Pemimpin instruksional berpengaruh terhadap tercapainya visi dan misi Lembaga; (15) Pemimpin instruksional mengintruksi cara-cara yang mudah untuk mengechek apakah suatu pekerjaan telah atau belum dilaksanakan; (16) Pemimpin menginstruksi mengenai fleksibel dalam menggunakan waktu dan sumber-sumber untuk meningkatkan proses dan hasil belajar peserta didik; (17) Sebagai pemimpin instruksional kepala sekolah juga memperhatikan problem yang peserta didik hadapi; (18) Kepala sekolah menginstruksi hal-hal yang dapat menarik minat peserta didik untuk meningkatkan proses belajar dan hasil belajar; (19) Kepala sekolah menekankan pelaksanaan kegiatan dengan kualitas yang tinggi agar dapat meningkatkan proses belajar dan hasil belajar peserta didik; (20) Secara kesuluruhan kepala sekolah dengan model kepemimpinan instruksional dibutuhkan 
untuk meningkatkan proses belajar dan hasil belajar peserta didik.

Temuan pengaruh kepemimpinan instruksional ini mendukung penelitian (Werang; 2014) yang menyimpulkan bahwa kepemimpinan instruksional berpengaruh secara signifikan terhadap kinerja guru. Dalam hal ini guru merupakan perantara antara kepala sekolah dengan peserta didik yang secara tidak langsung menerangkan kepemimpinan instruksional yang diimpelentasikan mmepengaruhi peningkatan kecerdasan peserta didik dengan meningkatkan keaktifan belajar dan hasil belajar peserta didik.

\section{KESIMPULAN}

Berdasarkan uraian hasil penelitian dan pembahasan di atas, dapat disimpulkan hal-hal seperti berikut.

Kepemimpinan instruksional adalah salah satu kepemimpinan yang komperhensif dan mempunyai potensi tinggi untuk meningkatkan prestasi sekolah. Dengan kepemimpinan instruksional kepala sekolah, guru-guru menjalankan tanggungjawab dengan tugasnya sebagai seorang guru terutama terfokusnya guru pada peningkatan keaktifan belajar dan mutu hasil belajar peserta didik. Strategi kepemimpinan instruksional yang diimplementasikan adalah cara praktis yang menjadi pegangan dalam menjalankan tugas kepemimpinanya dimana menjadi panutan atau model masyarakat sekolah, menciptakan iklim dan budaya sekolah yang kondusif, meninjau peningkatan mutu pembelajaran serta memperhatikan kebutuhan yang menjadi pendukung berjalanya kegiatan belajar mengajar dalam kelas. Dapat disimpulkan ada pengaruh model kepemimpinan instruksional terhadap peningkatan keaktifan belajar peserta didik yang ditunjukan oleh koefisien korelasi sebesar 0,762. Ada pengaruh model kepemimpinan instruksional terhadap hasil belajar peserta didik dengan nilai korelasi sebesar 0,797 , dan ada pengaruh kepemimpinan instruksional terhadap peningkatan keaktifan belajar dan hasil belajar peserta didik yang ditunjukan pada koefisien korelasi ganda sebesar 0,601. Simpulan penelitian ini bahwa kepemimpinan instruksional efektif meningkatkan kualitas pembelajaran

\section{SARAN}

Berdasarkan temuan serta hasil penelitian ini diantaranya: (1) kepemimpinan kepala sekolah diharapkan lebih aktif menginstruksi agar dapat membangun komunikasi yang baik dan terarah dalam melaksanakan program kerja dalam sekolah; (2) kepala sekolah diharapkan berbaur dengan stakeholder lainya agar dapat mengetahui kekurangan dalam pekerjaan yang dilakukan oleh bawahan sehingga mudah untuk mengarahkan; (3) untuk penelitian lebih lanjut menambah objek penelitian.

\section{DAFTAR PUSTAKA}

Bush, T. (2008). Leadership and management development in education. Sage.

Covey, S. R., Whitman, B., \& England, B. (2010). Cara mencapai hasil yang dapat diprediksi dalam waktu yang tidak dapat diprediksi. Management Press.

Gill, R. (2009). Theory and Partice of leadership. London: Sage.

Hallinger, P., \& Murphy, J. (1986). Instructional Leadership in Effective Schools.

Hallinger, P. (2005). Instructional leadership and the school principal: A passing fancy that refuses to fade away. Leadership and policy in schools, 4(3), 221-239.

Hallinger, P., \& Murphy, J. (1985). Assessing the instructional management behavior of principals. The elementary school journal, 86(2), 217-247.

Ubben, G. C., Hughes, L. W., \& Norris, C. J. (2001). The principal: Creative leadership for effective schools. Allyn \& Bacon/Longman Publishing, a Pearson Education Company, 1760 Gould Street, Needham Heights, MA 02494. Web site: http://www. abacon. com.

Marks, H. M., \& Printy, S. M. (2003). Principal leadership and school performance: An integration of transformational and instructional leadership. Educational administration quarterly, 39(3), 370-397.

Sugiyono. (2012). Metode Penelitian Kuantitatif Kualitatif dan R\&D. Bandung: Alfabeta.

Smith, C. S., \& Piele, P. K. (2012). School Leadership: Handbook for Excellent in Student Learning. Thousand Oak. 
Usman, H. (2015). Model kepemimpinan instruksional kepala sekolah. Jurnal Cakrawala Pendidikan, 34(3).

Werang, B. R. (2014). Pengaruh kepemimpinan transformasional kepala sekolah, moral kerja guru, dan kepuasan kerja terhadap kinerja guru SDN di Kota Merauke. Jurnal Cakrawala Pendidikan, 33(1).

Whitehead, B. M., Boschee, F., \& Decker, R. H. (2012). The principal: Leadership for a global society. Sage Publications. 